\title{
Factors Affecting Impulse Buying toward Fashion Products in Ho Chi Minh City - A Mediation Analysis of Hedonic Purchase
}

\author{
Mai Ngoc Khuong and Ta Bao Tran
}

\begin{abstract}
This research aimed to explore the direct and indirect effects of consumer's intrinsic variables on the impulse buying of customers toward fashion products in Ho Chi Minh City, Vietnam. Guided by impulse buying literature and previous research studies, the theoretical framework and hypotheses were developed to examine whether consumer behaviors including consumer's need for uniqueness, consumer self-spending control, novelty-fashion consciousness and optimum stimulation level affected hedonic purchase which, in turn, influenced the impulse buying characteristic. Data were collected by using a structure questionnaire from 355 respondents in four most famous fashion malls in Ho Chi Minh City. Multiple Regressions and Path analysis were applied as main methods to test the hypotheses of the study. As a result, this study found direct impacts of consumer's need for uniqueness and optimum stimulation level on impulse buying while hedonic purchase did moderate the effects of consumer self-spending control and novelty-fashion consciousness on impulse buying behavior. The results from this paper would be applied for both overseas and local fashion brands/retails to implement and turn into practical marketing activities to attract more impulse buyers.
\end{abstract}

Index Terms-Impulse buying, indirect effects, hedonic purchase, intrinsic variables, fashion products.

\section{INTRODUCTION}

Impulse buying is a major research concern among researchers due to its pervasive aspects of consumer behavior as well as its mystery in the marketing world. However, most of the study on impulse purchase concentrated on the external features impulse buying while fail to provide internal variables, which also caused impact on this consumer behavior. Besides, results from past studies shows that the extrinsic variables did not support much to the increasing of impulse buying of consumers. As a result, it is necessary to explore more important internal as well as mediator variables which are expected to cause stronger effect on impulse buying to provide a better understanding of the impulse buying concept and assist more appropriate marketing decisions in the field of marketing activities.

On the other hand, shopping has long been explored as an endless demand for human being, thus, people are easily to fall into impulse purchase when they do not even tend to buy these products, or do not need as a must-have-item in the

Manuscript received April 29, 2015; revised August 15, 2015

Mai Ngoc Khuong and Ta Bao Tran are with the School of Business, International University, VNU-HCM, Vietnam (e-mail: mnkhuong@hcmiu.edu.vn, trantb.ssc@gmail.com). volume from department stores is generated by impulse purchases. Ref. [2] also gave more evidence on the power of impulse buying by showing that around $\$ 4.2$ billion of total revenue gained in fashion stores originated from impulse buying.

However, most research paper conducted about impulse buying has origin from developed countries such as United States, the United Kingdom [3]-[5] and Singapore as [6] Almost no previous research study about impulse buying has empirically examined in developing countries before until this paper was conducted in Vietnam-a promising developing country. As reported by [7], in 2014, GDP per capita of Vietnam reached to US $\$ 1,030$. Furthermore, total personal disposable income of Vietnam was US\$127 billion in 2013. Next, the total consuming volume of Vietnamese consumers was about US\$111 billion in the same year [8]. About Vietnam's retail sales, which already reached to 53.9 billion USD in 2011 in total volume, is forecasted to grow up to 109 billion USD in 2017 [9]. Especially Ho Chi Minh City - the most dynamic city as well as the economic central of Vietnam, had the retail's sales up to US\$28.9 billion in 2013 [10]. Therefore, Ho Chi Minh City, especially fashion malls in this city, were chosen as sampling locations to conduct this research since impulse buying is expected to occur in these potential locations.

Regarding above explanations, this study aims to do an empirical investigation of the casual relationships between consumer's need for uniqueness and self-spending control, novelty fashion consciousness, optimum stimulation level and hedonic purchase on the impulse buying. Besides, it also predicts the mediating role of hedonic purchase to impulse buying as well as gives recommendations for marketing practitioners and merchandisers in improving the sales of clothing products in fashion malls by implementing the advantages of impulse buying.

\section{LITERATURE REVIEW}

\section{A. Impulse Buying}

Early marketing literature defined impulse buying in a simple way as unplanned purchasing [11]. Until [12], impulse buying was redefined as "a consumer experiences a sudden, often powerful and persistent urge to buy something immediately". In other words, impulse buying can be understood as an immediate and sudden purchase behavior with no thoughtful or future implications before. Also, 
impulse buyers are claimed to have unreflective thinking, which is "prompted by physical proximity to a desired product, dominated by emotional attraction to it, and absorbed by the promise of immediate gratification [13]. Thus, it can be inferred that impulse buying occurs frequently and strongly in highly impulsive buyers than other consumers.

\section{B. Hedonic Purchase}

According to [14], hedonic purchase is referred to "emotional needs of individuals for enjoyable and interesting shopping experiences". As discussed by [15], hedonic buying motive relates to emotional arousal, which happens while carrying out purchasing process. In other words, hedonic purchase occurs in a high - involvement situation, where any single individual has a deep fall into a consumption event [16]. Therefore, the changing levels of involvement have positive influence on the level of hedonism. The level of hedonism is estimated to be higher in high - involvement consumption situations and vice versa. Besides, [17] classified impulse buying as hedonic behavior that is incorporated with feelings and psychosocial incitements. Besides, research by [18] demonstrates that impulse purchasing is incorporated with sensory stimulation and hedonic motivation. Recently, as suggested by [19] shopping value of a person results in impulse purchase and is inseparably associate with each other. Thus, thanks to the support from relevant literature, it can be hypothesize a direct positive relationship between hedonic purchase and impulse buying.

\section{Consumer's Need for Uniqueness}

In a study implemented by [20], consumer's need for uniqueness is defined as "the trait of pursuing differences relative to others through the acquisition, utilization, and disposition of consumer goods for the purpose of developing and enhancing one's self-image and social image". Therefore, consumer's need for uniqueness is claimed to be associated with products which have some symbolic meanings to enhance individual's self and social image as an expression of uniqueness. Followers pursuing the development of a distinguishing trait or to share general connections with prior groups of adopter are attracted by purchaser selections, or creative selections in particular, which can initialize one's distinct [21]. In other words, new products or brands can be acquired more rapidly by purchasers who have greater demand of distinction than those having that demand at a lower level [22]. Thus, it can be inferred that there has a positive relationship between the consumer's need for uniqueness and impulse buying.

Also, consumer's need for uniqueness is predicted to have direct impact on hedonic purchase, which implies those customers have strong interested in shopping experience. Regarding above explanations, hedonic purchase plays mediator role in the relationship between consumer's need for uniqueness and impulse buying.

\section{Consumer Self-Spending Control}

According to [23], consumer spending self-control describes individuals having ability to regulate themselves from spending, or self-regulations in other words. As discussed by [24], individuals having greater self-control administer their finance more appropriate than the others as well as preserving more and expending less. Individuals having low self-control are unprotected to be attracted by the moment, and a sales pitch focusing on instantaneous satisfaction would be engaging. On the other hand, individuals having greater self-discipline persuasively consider long-term value and advantages before purchasing. Thus, impulse buying occurs when the desire of customers for a product beats their intentions to avoid purchasing [25]. This indicates that the need to purchase and the capability of self-control are two discrete procedures taken into account with impulse buying.

Besides, as [26], self-control is recognized as associated with hedonic and utilitarian consumption. According to [27], hedonic consumption can generate more negative self-control than utilitarian consumption, which means individual with low self-spending control will easily to fall in hedonic consumption over the other. Consequently, the purchaser having low self-discipline tends to have hedonic purchase. Additionally, since low-self spending control people will repeat impulse buying practice, a conclusion can be withdrawn that there has a positive indirect relationship between consumer's self-spending control and impulse buying which mediated by hedonic purchase.

\section{E. Novelty-Fashion Consciousness}

As simply defined by [28], novelty - fashion consciousness is a characteristic that describes individuals who are fashionable with novelty conscious and love to experience new things, while impulse buyers are labeled as individuals' tendency to have spontaneous, unreflective, immediate and kinetic buying motives. As proved, impulse buyers will have faster approach to buying ideas and have "opening" shopping lists at any time. Additionally, [29] developed a consumer decision-making style inventory (CSI), which helps define and evaluate eight mental traits of consumer in decision making. Among eight consumer's characteristics, novelty-fashion consciousness and impulsiveness are mentioned as traits which have greater impact towards consumption Thus, it can be inferred that buyers with novelty and fashion consciousness are likely to experience impulse purchase.

In addition, customers with high novelty-fashion consciousness always seek for new fashions and fads with excitement and pleasure. These characteristics are similar to consumer hedonic purchase behavior, which describes individuals with high demand for shopping experience for enjoyment. Therefore, this research study expects a positive direct relationship between novelty-fashion consciousness and hedonic purchase.

To sum up, this study hypothesizes a positive relationship between novelty-fashion consciousness and impulse buying, which can be mediated by hedonic purchase.

\section{F. Optimum Stimulation Level}

As discussed by [30]-[31], individuals with high optimum stimulation level have lower arousal level which encourages them to seek for activities in order to reach their desired stimulation level. In other words, those who have low optimum stimulation level can comfortably satisfy with 
commonplace situation while individuals having high optimum stimulation level can easily have negative feelings in a steady and usual environment since they have higher propensity to discover latest inducement to fulfil their demand on stimulations [32]-[33]. In addition, new experiences tends to be accepted straightforwardly by group having high optimum stimulation level [34]-[35] and thus they are more engaging and willing to check out new products, services and brands [33], [36]. Accordingly, individuals with high optimum stimulation level are likely to have indulgence in impulse buying.

Also, this study predicted that optimum stimulation level is engaged in a significant positive relationship with hedonic consumption thanks to the same interest in seeking for new things. In summary, a direct relationship between optimum stimulation level and hedonic purchase is developed by theories. As well, hedonic purchase also plays a mediator role in the relationship between optimum stimulation level and impulse buying.

\section{G. The Theoretical Framework}

In order to obtain all the objectives and further analyses, this study hypothesizes that:

$\mathrm{H}_{1.1}$ : Consumer's need for uniqueness directly affects hedonic purchase .

$\mathrm{H}_{1.2}$ : Consumer self-spending control directly affects hedonic purchase.

$\mathrm{H}_{1.3}$ : Novelty fashion consciousness directly affects hedonic purchase.

$\mathrm{H}_{1.4}$ : Optimum stimulation level directly affects hedonic purchase.

$\mathrm{H}_{2.1}$ : Consumer's need for uniqueness directly affects hedonic purchase.

$\mathrm{H}_{2.2}$ : Consumer self-spending control directly affects hedonic purchase.

$\mathrm{H}_{2.3}$ : Novelty fashion consciousness directly affects hedonic purchase.

$\mathrm{H}_{2.4}$ : Optimum stimulation level directly affects hedonic purchase.

$\mathrm{H}_{2.5}$ : Hedonic purchase directly affects impulse buying.

$\mathrm{H}_{3.1}$ : The effect of consumer's need for uniqueness on impulse buying is mediated by hedonic purchase.

$\mathrm{H}_{3.2}$ : The effect of consumer self-spending control on impulse buying is mediated by hedonic purchase.

$\mathrm{H}_{3.3}$ : The effect of novelty fashion consciousness on impulse buying is mediated by hedonic purchase.

$\mathrm{H}_{3.4}$ : The effect of optimum stimulation level on impulse buying is mediated by hedonic purchase.

\section{MethodOlOGY}

\section{A. Questionnaire Design and Data Collection}

This research paper applied quantitative approach with designed structure questionnaire with most of the items using five-point scale (from $1=$ strongly disagree to $5=$ strongly agree).

Since the research topic covers the impulse buying behavior toward fashion products in Ho Chi Minh City, data were mainly collected in shopping malls to ensure the quality of the data as well as avoid bias. Besides, almost buyers could not remember whether they did make an impulse purchase or not if they were not at shopping malls at the time they were asked, thus, most of the data were collected in hand at the malls. Due to the limit of time and geographical barriers, four well-known shopping malls were chosen as sampling locations, which are Diamond Plaza, Vincom Center, Parkson Hung Vuong and Cresent Mall.

The pilot test was conducted at first with 90 respondents to test the comprehensiveness and possibility of the survey. After that, a total number of 265 cases was collected in good quality.

\section{B. Data Analysis}

SPSS statistical software was used to analyze collected data. In order to test the validity and reliability of the data, Cronbach's Alpha was applied. Additionally, Factor analysis (Exploratory Factor Analysis - EFA) was employed to attain the amount of factors that would give explanation on the maximum variance in the data. Lastly, multiple regression and path analysis were conducted to examine the hypotheses.

\section{Factor Analysis and Reliability}

In this study, two exploratory factor analsysis (EFA) were conducted; one for the group of the dependent variables and one for the group of independent variables. Kaiser-Meyer-Olkin and Barlett's test with Varimax rotation and Principal Component Analysis extraction method were performed. As a result, the KMO index for both dependent variables $(\mathrm{KMO}=.919)$ and independent variables $(\mathrm{KMO}=.875)$ were above 0.6 , which is in a good range of analysis [37]. Additionally, Barltlett's test of Sphericity of both groups was significant $($ Sig. $=.000)$, which implies sufficient correlation between these factors.

Table I indicates the result of dependent variables, which are hedonic purchase and impulse buying. The factor loading of all items are well-above the minimum requirement (.4) [38], ranging from .662 to .871 . The Cronbach's alpha values which measures the internal consistency between items in hedonic purchase and impulse buying were .934 and .868 respectively. Ref. [39] reported that Cronbach's Alpha is acceptable when equals to .6 , and good when the value exceeds .7.

TABLE I: SUMMARY OF DEPENDENT VARIABLES

\begin{tabular}{lcc}
\hline Factors & $\begin{array}{c}\text { Number of } \\
\text { Items }\end{array}$ & $\begin{array}{c}\text { Cronbach's } \\
\text { Alpha } \\
(\mathbf{N = 2 6 5})\end{array}$ \\
\hline Factor 1: Hedonic Purchase (HEDPER) & 9 & .934 \\
Factor 2: Impulse Buying (IMBU) & 5 & .868 \\
\hline
\end{tabular}

TABLE II: SUMMARY OF INDEPENDENT VARIABLES

\begin{tabular}{lcc}
\hline \multicolumn{1}{c}{ Factors } & $\begin{array}{c}\text { Number } \\
\text { of Items }\end{array}$ & $\begin{array}{c}\text { Cronbach's } \\
\text { Alpha } \\
(\mathbf{N = 2 6 5})\end{array}$ \\
\hline 1. Consumer Self-Spending Control (COSESPCO) & 9 & .892 \\
2. Consumer's Need for Uniqueness (CONEFUN) & 6 & .892 \\
3. Optimum Stimulation Level (OPSTILE) & 4 & .826 \\
4. Novelty Fashion Consciousness (NOFACON) & 4 & .865 \\
\hline
\end{tabular}

Likewise, the factor loadings of all items in independent groups are also higher than .4 and ranges from .509 to .864 . Besides, the Cronbach's coefficient alpha values among independent variables were above .7 , which equals $.892, .892$, 
$.826, .865$ for consumer self-spending control, consumer's need for uniqueness, optimum stimulation level and novelty -fashion consciousness in that order as presented in Table II.

\section{RESEARCH FINDINGS}

\section{A. Profile of the Sample}

TABLE III: DEMOGRAPHIC INFORMATION $(N=265)$

\begin{tabular}{llcc}
\hline & Details & Frequency & Percentage \\
\hline \multirow{3}{*}{ Gender } & Male & 111 & 34.7 \\
& Female & 209 & 65.3 \\
\hline \multirow{5}{*}{ Occupation } & $15-18$ & 7 & 2.2 \\
& $19-30$ & 302 & 94.4 \\
& $31-40$ & 9 & 2.8 \\
& $>40$ & 2 & 0.6 \\
\hline \multirow{5}{*}{ Income } & Students & 266 & 83.1 \\
& Office Executive & 36 & 11.3 \\
& Retailer/ Housewife & 2 & 0.6 \\
& Executive (Engineer, & 5 & 1.6 \\
& Doctor, Teacher) & & \\
& Others & 11 & 3.4 \\
\hline & <3 million VND & 194 & 60.6 \\
& 3-7 million VND & 79 & 24.7 \\
& $8-15$ million VND & 31 & 9.7 \\
& $>15$ million VND & 16 & 5 \\
\hline
\end{tabular}

In Table III, the data of respondent profiles were summarized into important categories such as gender, age, occupation and monthly income with purpose of classifying the group of customers. About gender, it can be seen clearly that the percentage was higher in female buyers with nearly $65.4 \%$ while it only took approximately $34.7 \%$ in male. Next, according from the respondents' age, the highest percentage of the age group lied in the range from 19 - 30 years old with the proportion up to $94 \%$. As can be explained, $19-30$ was the age group that buyers are usually concerned about fashion trend and easily have impulse purchase based on their financial budgets. Besides, $3 \%$ are buyers at the age of $31-$ $40,2 \%$ from $15-18$ years old and there is only $1 \%$ of buyers with age over 40. Table III continuously demonstrated the percentage of occupation of the respondents. There were $83 \%$ are students, $11 \%$ of office executive (including ILA's staffs and other officers), $2 \%$ are retailers and housewives, $1 \%$ are executives which are engineers, doctors, teachers and the others job accounts for $3 \%$. Finally, in the income group, the lower-middle income accounted for $60 \%$ of the total respondents and was the highest income among the 3 groups. It can be explained that the students were the largest respondents, thus, the income level of these students usually ranges from under to 3 million VND. Besides, middle income level (3 - 7 million VND) took the second place with $25 \%$, upper-middle income level ( 8 - 15 million VND) lied in third place with $10 \%$ and the high income level (> 15 million VND) had the lowest proportion with only $5 \%$.

\section{B. Factors Affecting Impulse Buying}

\section{1) Correlation between variables}

Table IV demonstrates that there were positive correlations between dependent variable (IMBU) and three independent variables of CONEFUN $(r=.435, p<.05)$, OPSTILE $(r=.369$, $p<.05)$, and NOFACON $(r=.631, p<.05)$, and the mediating variable of HEDPER $(r=.566, p<.05)$, while the independent variable of COSESPCO ( $r=-.179, p<.05)$ had negative correlations with dependent variable (IMBU). These results indicated that individuals with higher needs for uniqueness, optimum stimulation level, novelty-fashion consciousness, and hedonic purchase are likely to have higher level of impulse buying behavior. On the other hand, people with higher level of self-spending control are likely to have lower level of impulse buying behavior.

TABLE IV: PEARSON CORRELATIONS BETWEEN VARIABLES OF THE

\begin{tabular}{lccccc}
\multicolumn{7}{c}{ RESEARCH MODEL } \\
\hline \multicolumn{7}{c}{ IMBU } & $\mathbf{1}$ & $\mathbf{2}$ & $\mathbf{3}$ & $\mathbf{4}$ \\
\hline 1. COSESPCO & $-.247^{*}$ & 1.000 & & & \\
2. CONEFUN & $.448^{*}$ & .061 & 1.000 & & \\
3. OPSTILE & $.354^{*}$ & $.103^{*}$ & $.309^{*}$ & 1.000 & \\
4. NOFACON & $.523^{*}$ & -.057 & $.576^{*}$ & $.310^{*}$ & 1.000 \\
5. HEDPER & $.566^{*}$ & $-.179^{*}$ & $.435^{*}$ & $.369^{*}$ & $.63^{*}$ \\
\hline Mean & $\mathbf{3 . 2 0}$ & $\mathbf{3 . 4 8}$ & $\mathbf{2 . 9 2}$ & $\mathbf{3 . 8 3}$ & $\mathbf{3 . 0 7}$ \\
\multicolumn{1}{c}{ SD. } & $\mathbf{. 8 1 2}$ & $\mathbf{. 6 9 3}$ & $\mathbf{. 8 5 4}$ & $\mathbf{. 6 9 2}$ & $\mathbf{. 9 0 7}$ \\
\hline
\end{tabular}

Note: * Significant level at $p<.05$.

\section{2) Direct effects of independent variables on hedonic} purchase

TABLE V: EFFECT COEFFICIENTS BETWEEN IVS AND HEDPER

\begin{tabular}{lccc}
\hline Variables & $\begin{array}{c}\text { Unstandardized } \\
\text { Coefficients }\end{array}$ & t-value & Sig. \\
\hline & 1.390 & 4.541 & .000 \\
1. COSESPCO & -.228 & -3.831 & .000 \\
2. CONEFUN & .096 & 1.627 & .105 \\
3. OPSTILE & .261 & 4.146 & .000 \\
4. NOFACON & .499 & 8.910 & .000 \\
\hline Note: Dependent Variable: HEDPER: Hedonic Purchase \\
- Predictors: COSESPCO, CONEFUN, OPSTILE, NOFACON \\
- ANOVA: $F(4,260)=56.547$, Sig. $=000, p<.05$. \\
- Model summary: $R^{2}=.465$.
\end{tabular}

As can be seen from Table V, the R Square is .465, which means that $46.5 \%$ of variance in the mediating variable (Hedonic purchase) is explained by the independent variables. However, the relationship was only recognized as significant if significant value was smaller than .05 [40]. As a result, Consumer's need for uniqueness (CONEFUN) was not significant $(.105>.05)$, thus, only OPSTILE $(B=.260, p<.05)$ and NOFACON $(B=.499, p<.05)$ provided positively direct effects on HEDPER. Besides, COSESPCO $(B=-.228, p<.05)$ had negatively direct impact on HEDPER. This means every 1 standard deviation changed in OPSTILE, or NOFACON, or COSESPCO would lead to an increase in HEDPER of .260 or .499 , respectively, or a decrease in HEDPER of -.228 while other variables were controlled for.

\section{3) Direct effects of independent variables on impulse buying}

The result from Table VI shows that $R^{2}=.443$, which means that $44.3 \%$ of variance in dependent variable (IMBU) is explained by the research model. As a result, all the independent variables' significant values were smaller than .05 . Thus, it can be concluded that only COSESPCO $(B=-.253$, $p<.05)$ had significantly negative effect on IMBU while the other independent variables including CONEFUN $(B=.180$, $p<.05)$, OPSTILE $(B=.189, p<.05)$, NOFACON $(B=.162$, $p<.05)$, and HEDPER $(B=.246, p<.05)$ provided significantly positive effects on IMBU. This means that every 1 standard 
deviation of change in COSESPCO, or CONEFUN, or OPSTILE, or NOFACON, or HEDPER would lead to a decrease in IMBU of -.253 and an increase in IMBU of .180, or 189 , or 162 , or 246 , respectively.

TABLE VI: EFFECT COEFFICIENTS BETWEEN IVS AND IMBU

\begin{tabular}{|c|c|c|c|}
\hline Variables & Unstandardized Coefficients & t-value & Sig. \\
\hline & 1.494 & 5.067 & .000 \\
\hline 1. COSESPCO & -.253 & -4.472 & .000 \\
\hline 2. CONEFUN & .180 & 3.250 & .001 \\
\hline 3. OPSTILE & .189 & 3.141 & .002 \\
\hline 4. NOFACON & .162 & 2.733 & .007 \\
\hline 5. HEDPER & 246 & 4.274 & .000 \\
\hline
\end{tabular}

Note: Dependent Variable: IMBU: Impulse Buying

-Predictors: COSESPCO, CONEFUN, OPSTILE, NOFACON, HEDPER

-ANOVA: $F(5,259)=41.216$, Sig. $=000, p<.05$

-Model summary: $R^{2}=.443$

\section{4) Significant of indirect effects}

In this part, bootstrapping method was applied as suggested by [41] to examine the significance of indirect effects as well as obtain confident intervals in mediation model. The bootstrapped confidence interval was at $95 \%$. As explained by [42], if a zero (0) occurred between the lower boundary (LL) and the upper boundary (UL), it could be said in $95 \%$ of confidence that mediation or indirect effect would not exist. On the contrary, if zero did not lie within the interval range between the LL and the UL, then it could be concluded with 95\% of confidence that the indirect effect was significant, or the mediation was acceptable. According to the results from Table VII, the indirect effect of COSESPCO on IMBU through the mediation of HEDPER which was calculated fell within the range of -.0909 (LL) and -.0262 (UL). Similarly, the indirect effect of OPSTILE and NOFACON on IMBU which were mediated by HEDPER also lied in the range from .0318 to .1028 and from .0728 to .1773 . As can be seen clearly, zero did not occur in these ranges, or was not in the 95\% confidence interval in other words, thus, it can be concluded that the indirect effects of COSESPCO, OPSTILE and NOFACON on IMBU were certainly significant and different from zero at $\mathrm{p}<.05$ (two tailed). This also means that the mediating role of HEDPER in this research was true.

TABLE VII: DIRECT, INDIRECT, AND TOTAL CAUSAL EFFECTS

\begin{tabular}{lccccc}
\hline Variables & \multicolumn{3}{c}{ Causal effects } & \multirow{2}{*}{ LL } & UL \\
\cline { 2 - 4 } & Direct & Indirect & Total & & \\
\hline 1. COSESPCO & -.253 & -.056 & -.309 & -.0909 & -.0262 \\
2. OPSTILE & .189 & .064 & .253 & .0318 & .1028 \\
3. NOFACON & .162 & .123 & .285 & .0728 & .1773 \\
4. CONEFUN & .180 & ---- & .180 & & \\
5. HEDPER & .246 & ---- & .246 & & \\
\hline Total & $\mathbf{. 5 2 4}$ & $\mathbf{. 1 3 1}$ & $\mathbf{. 6 5 5}$ & & \\
\hline
\end{tabular}

\section{5) The causal effects of impulse buying}

Table VII presented briefly the causal effects of independent variables (consist of direct and indirect effects) and mediating variable on Impulse buying. Regarding the results above, COSESPCO had strongest negative impact on IMBU with ( $\beta=-.309)$. Followed right after was NOFACON, which caused positive influence on IMBU $(\beta=.285)$. CONEFUN had the weakest effect on IMBU with $\beta$ value only equals .180. The total effect of these factors on IMBU was .655, which direct effects of COSESPCO, CONEFUN, OPSTILE, NOFACON and HEDPER took a large percentage of exact $80 \% \quad(\beta=.524)$ while the indirect effects of COSESPCO, OPSTILE and NOFACON on IMBU only accounted for $20 \%$.

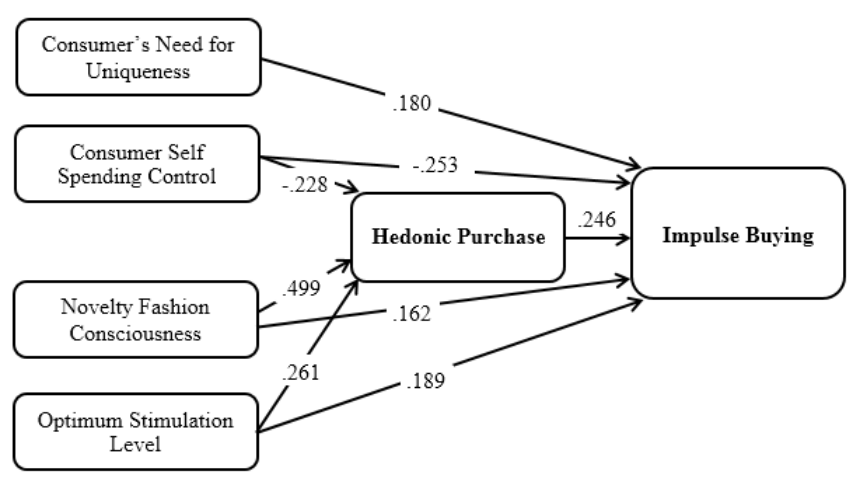

Fig. 1. Path coefficients of hypothesis testing

Note: All coefficients in the model were significant at the .05 level.

The Fig. 1 above illustrated the causal effects of independent variables and mediating variable on Impulse buying by graph. To summarize, CONEFUN was the factor that only caused direct effect on IMBU while COSESPCO, NOFACON and OPSTILE had both direct and indirect impacts on IMBU, which was mediated by HEDPER.

\section{DISCUSSIONS AND RECOMMENDATIONS}

\section{A. Discussions}

This study attempted to provide a more comprehensive research model in which the intrinsic variables play main role in affecting impulse buying of customers, and the results of were well supported for the conceptual framework. In summary, the statistical findings demonstrated that consumer self-spending control, optimum stimulation level and novelty-fashion consciousness not only had direct impact on impulse buying, but also affect directly impulse buying through hedonic purchase. Besides, consumer's need for uniqueness also had directly positive influence on impulse buying. This means that customers with low self-control, high demand for uniqueness, strong interest in fashion and great desire for experiencing new things may get deeper involvement in impulse buying than normal people. This finding received support from some past studies of impulse buying including [18]-[36]. These authors did examine the existence of some significant relationships between impulse buying and independent variables, however, in their findings, the mediating role of hedonic purchase was not explored. Furthermore, prior researches, which investigated mainly on individual differences (e.g. shopping enjoyment) or situational variables (e.g. time and money available) in the context of shopping had low R Squared values in their regression models. It can be explained that intrinsic variables may play important role in increasing impulse buying behavior of customers rather than extrinsic or situational variables. Perhaps, this research model hypothesized and examined some predicted relationships between potential independent variables and impulse buying, and it can be 
confidentially reported that this research's conceptual framework was highly recognized in Vietnam fashion market since all the hypotheses were accepted as well as the regression model of this study produced higher $\mathrm{R}$ Squared value $(45 \%)$. However, lacking of time and budget prevents the researchers from choosing larger sample size to gain more valuable results, therefore, small sample size cannot represent the population so the main findings may be inaccurate somehow. Besides, geographical problems are great barriers to broaden the market in collecting data, thus, only four fashion malls in Ho Chi Minh City were chosen to deliver paper questionnaires. In short, future researches should extend the sample size to decrease the bias and increase the validity as well as the reliability in the data collected. In addition, the further investigation also gets advantage from this study by replicating it in the new research setting or another industry in Vietnam market. It would be interesting if the replication in another industry or market brought reversed results and give different point of views among consumers about factors affect impulse buying.

\section{B. Recommendations for Retailers and Fashion Brands}

On the aspect of practical applications, retailers as well as fashion brands need to focus most on factors which cause strongest impact on impulse buying motives to enhance the sales and revenues. As can be inferred from the research result, consumer self-spending control caused the greatest negative impact on impulse buying directly, while the indirect relationship between novelty-fashion consciousness and impulse buying mediated by hedonic purchase came at second with the significant positive influence on impulse buying. Thus, consumer self-spending control, novelty-fashion consciousness and hedonic purchase were explored as factors that play the main role to consumer's impulsiveness. Thus, it would lead to the following issues for the retail stores to be concentrated on:

Firstly, to increase impulse buying, it is a must to reduce the customers' saving awareness. As proved, only individuals with low self-control easily enter to impulse buying behavior. Therefore, fashion brands or retailers should launch "Loyalty customers programs" to encourage customers to engage in shopping as good habits. Specific benefits should be announced to customers such as gifts on birthday, discount over $30 \%$ on new arrival items, or increase the discount portion when customers upgrade their cards. Secondly, if retailers/fashion brands want to attract customers with novelty and fashion consciousness, the best advice for them is redesigning and decorating the store environment in the most distinct way, which can easily differentiate their fashion stores from others. Besides, clothing and accessories should be combined together to make out the most of the styles as well as encourage the consumers to buy the whole set instead of one shirt or jeans. More important, people with high fashion consciousness will not accept to buy cloths produced in a series and ready-to-wear fashion, thus, the fashion brands need to create unique designed items and produce in a very limited amount. These kind of customers will feel urge to buy "limited edition" products to fulfill their esteems.

Next, to enhance the spontaneous buying in hedonic consumers, fashion brands should launch many "Induction
Events" (an event which is held to introduce new collections of the brand) or Golden Day (an occasion aims to express deep gratitude to loyal customers by inviting them to private dinners as well as giving gifts or offering discount V.I.P cards for the next purchasing). Likewise, individuals with high level of hedonic consumption will easily attracted to the seasonal sales off or occasional discount due to the high demand for dressing smartly in such special events. Consequently, organizing events in a suitable timeline combined with releasing new collections regularly will encourage hedonic customers to shop more than their actual needs.

Finally, it can be said with some degree of confidence that these recommendations above would useful for those fashion brands or retailers if they applied them properly and smartly.

\section{CONCLUSIONS}

Since there is almost no previous research studies before found out factors which cause more than $50 \%$ of impact on level of impulse buying, this research study continued to conduct research on this topic on purpose of seeking factors that truly have strong influences on impulse purchase. In summary, the results completely matched with the hypotheses and the theoretical framework proposed in this study. Besides, the proposed theoretical framework has confirmed the important roles of optimum stimulation level, hedonic purchase, consumer's need for uniqueness, novelty- fashion consciousness as well as consumer self-spending-control. In general view, this research revealed that the causal relationships among these above independent variables and impulse buying were well significant. Specifically, since consumer self-spending control, novelty-fashion consciousness and hedonic purchase stand out as most important factors in increasing impulse buying, retailers or fashion brands should be aware of their roles and implement proper strategies to strengthen their level of influences on impulse buying. To summarize, the research's outcome did not only contribute some practical implications for retail industry but also give some theoretical implementations for further research studies.

\section{REFERENCES}

[1] D. N. Bellenger, D. H. Robertson, and E. C. Hirschman, "Impulse buying varies by product," Journal of Advertising Research, vol. 18, pp. 15-18, 1978 .

[2] M. Mogelonsky, "Keep candy in the aisles," American Demo-graphics, vol. 20, pp. 32, 1998.

[3] J. T. McConatha, E. Lightner, and S. L. Deaner, "Culture, age, and gender as variables in the expression of emotions," Journal of Social Behavior and Personality, vol. 9, pp. 481-488, 1994.

[4] G. Bayley and C. Nancarrow, "Impulsive purchasing: A qualitative exploration of the phenomenon," Qualitative Market Research, vol.1, no. 2, pp. 99-114, 1998.

[5] H. Dittmar, J. Beattie, and S. Friese, "Gender identity and material symbols: Objects and decision considerations in impulse purchases," Journal of Economic Psychology, vol. 16, pp. 491-511, 1995.

[6] P. N. Shamdasani and D. W. Rook "An exploratory study of impulse buying in an oriental culture: The case of Singapore," Singapore Marketing Review, vol. 4, pp. 7-20, 1989.

[7] Gross Domestic Product per Capita of Vietnam, Vietnam General Statistics Office, 2014

[8] Vietnam's total personal disposable income and total household consumption in 2008-2017, Retail in Vietnam, Emerging Market, Emerging Growth, Deloitte, p. 8. 
[9] Vietnam's retail sales in 2008-2017, Retail in Vietnam, Emerging Market, Emerging Growth, Deloitte, p. 10.

[10] Ho Chi Minh's retail sales in 2009-2013, Retail in Vietnam, Emerging Market, Emerging Growth, Deloitte, p. 17.

[11] C. J. Cobb and W. D. Hoyer, "Planned versus impulsive behavior," Journal of Retailing, vol. 62, no. 4, pp. 384-409, 1986.

[12] D. W. Rook, "The Buying Impulse," Journal of Consumer Research, vol. 14, no. 2, pp. 189-197, 1987.

[13] S. J. Hoch and G. F. Loewenstein, "Time-inconsistent Preferences and Consumer Self-control," Journal of Consumer Research, vol. 17, no. 4, pp. 492-507, 1991.

[14] A. Bhatnagar and S. Ghose, "A latent class segmentation analysis of E-Shoppers," Journal of Business Research, vol. 57, no. 7, pp. 758-767, 2004.

[15] E. C. Hirschman and M. B. Holbrook, "Hedonic consumption: Emerging concepts, methods and propositions," Journal of Marketing, vol. 46, pp. 92-101, 1982.

[16] G. C. Hopkinson and P. Davashish, "A factor analytic study of the sources of meaning of Hedonic consumption," European Journal of Marketing, vol. 33, no. 3, pp. 273-290, 1999.

[17] P. Sharma, B. Sivakumaran, and R. Marshall, "Impulse buying and Variety seeking: A trait-correlates perspective," Journal of Business Research, vol. 63, pp. 276-283, 2010.

[18] S. E. Beatty and M. E. Ferrell, "Impulse buying: Modeling its precursors," Journal of Retailing, vol. 74, no. 2, pp. 169-191, 1998.

[19] Y. Chunling and M. Bastin, "Hedonic shopping value and impulse buying behavior in transitional economies: A symbiosis in the Mainland China marketplace," Journal of Brand Management, vol. 18, no. 2, pp. 105-114, 2010.

[20] K. T. Tian, W. O. Bearden, and G. L. Hunter, "Consumers' need for uniqueness: scale development and validation," Journal of Consumer Research, vol. 28, no. 1, pp. 50-66, 2001.

[21] K. T. Tian and K. McKenzie, "The long-term predictive validity of consumers' need for uniqueness," Journal of Consumer Psychology, vol. 10, no. 3, pp. 1971-1973, 2001.

[22] D. K. Knight and E. Y. Kim., "Japanese consumers' need for uniqueness: Effects on brand perceptions and purchase intention," Journal of Fashion Marketing and Management, vol. 11, no. 2, pp. 270-280, 2007.

[23] K. L. Haws, W. O. Bearden, and G. Y. Nenkov, "Consumer spending self-control effectiveness and outcome elaboration prompts," Journal of Academy of Marketing Science, Forthcoming, vol. 1, pp. 3-4.

[24] J. B. Romal and B. J. Kaplan, "Difference in self control among spenders and savers, psychology," A Quarterly Journal of Human Behavior, vol. 32, no. 2, pp. 8-17, 1995.

[25] R. F. Baumeister, "Yielding to tempation: Self-control failure, impulse purchasing, and consumer behavior," Journal of Consumer Research, vol. 28 , no. 4, pp. 670-676, 2003.

[26] D. R. and K. Wertenbroch, "Consumer choice between hedonic and utilitarian goods," Journal of Marketing Research, vol. 37, pp. 60-71, 2003.

[27] U. Khan and O. Urminsky "navigating between virtues and vices: moderators of decisions involving hedonic versus utilitarian choices," Advances in Consumer Research, vol. 31, pp. 361.

[28] S. Bae, "Shopping pattern differences of physically active Korean and American university consumers for athletic apparel," Ph.D. dissertation, College of Education, The Florida State University, Florida, USA, 2004.

[29] G. B. Sprotles and E. L. Kendall, "A methodology for profiling consumer decision making styles," The Journal of Consumer Affairs, vol. 20, no. 2, pp. 67-79, 1986.
[30] P. S. Raju and M. Venkatesan, "Exploratory behavior in the consumer context," A State of the Art Review, vol. 7, pp. 258-263, 1980.

[31] S. J.-Benedict and B. Hans, "The role of optimum stimulation level in exploratory consumer behavior," Journal of Consumer Research, vol. 19, pp. 434-448, 1992.

[32] G. B. Kish and G. V. Donnenwerth, "Sex differences in the correlates of stimulus seeking," Journal of Consulting and Clinical Psychology, vol. 38, no. 1, pp. 42-49, 1972.

[33] P. S. Raju, "Optimum stimulation level: Its relationship to personality, demographics, and exploratory behavior," Journal of Consumer Research, vol. 7, no. 3, pp. 272-282, 1980.

[34] A. Aluja, Ó. García, and L. F. García, "Relationships among extraversion, openness to experience, and sensation seeking," Personality and Individual Differences, vol. 35, no. 3, pp. 671-680, 2003.

[35] R. E. d. Vries, A. d. Vries, and J. A. Feij, "Sensation seeking, risk-taking, and the HEXACO model of personality," Personality and Individual Differences, vol. 47, no. 6, pp. 536-540, 2009.

[36] J. B. E. M. Steenkamp and S. M. Burgess, "Optimum stimulation level and exploratory consumer behavior in an emerging consumer market," International Journal of Research in Marketing, vol. 19, no. 2, pp. 131-150, 2002.

[37] B. G. Tabachnick and L. S. Fidell, Using Multivariate Statistics, $4^{\text {th }}$ ed. New York: HarperCollins, 2001.

[38] F. Hair Jr., W. C. Black, B. J. Babin, R. E. Anderson, and R. L. Tatham, Multivariate Data Analysis, 6th ed. New Jersey: Prentice Hall, 2006.

[39] J. Pallant, SPSS Survival Manual: A Step by Step Guide to Data Analysis Using SPSS for Windows, 3rd ed. Open University Press, 2007.

[40] J. Pallant, SPSS Survival Manual, 4th ed. McGraw Hill, 2010.

[41] J. K. Preacher and A. F. Hayes, "Asymptotic and resampling strategies for assessing and comparing indirect effects in multiple mediator models," Behavior Research Methods, vol. 40, no. 3, pp. 879-891, 2008.

[42] J. K. Preacher and A. F. Hayes, "SPSS and SAS procedures for estimating indirect effects in simple mediation models," Behavior Research Methods, Instruments, \& Computers, vol. 36, no. 4, pp. 717-731, 2004.



Mai Ngoc Khuong is a lecturer and researcher of School of Business Administration, International University, Vietnam National University, Ho Chi Minh City. He has a bachelor degree in tourism and hospitality management, a master of science degree in leisure, tourism and environment at Wageningen University, The Netherlands, and a $\mathrm{PhD}$ degree in development management at School of Public Administration of the National Institute of Development Administration (NIDA), Bangkok, Thailand.

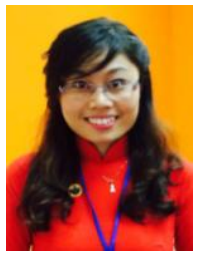

Ta Bao Tran is a research assistant in School of Business Administration, International University, Vietnam National University, Ho Chi Minh City. She was born in Ho Chi Minh City on December 11, 1993. She holds a bachelor degree in business administration, majoring in marketing at International University, Vietnam National University and continues to strengthen her career profile with a master of science degree in business management at the University of the West of England, Bristol, UK 